\title{
The Current Status of Ethnobiology in Ecuador
}

\author{
Tania González-Rivadeneira $^{1 *}$, Radamés Villagómez-Reséndiz ${ }^{1,2}$, Alessio Barili $^{1}$ \\ ${ }_{*}^{1}$ Sociedad Ecuatoriana de Etnobiología ${ }^{2}$ Estudios Mesoamericanos, National Autonomous University of México \\ taniaivanovagr@gmail.com
}

\begin{abstract}
This article gives an account of the current status of ethnobiology in Ecuador. Our goal is a generalized diagnosis of Latin America's ethnobiological research production, which portrays Ecuadorian ethnobiology as practically non-existent. We perform an updated search of online databases, using a range of keywords, to show that elements of an ethnobiological research program are indeed present in Ecuadorian scholarship. While ethnobotany is the most developed sub-discipline of ethnobiology in Ecuador, there is also research on ethnomedicine, ethnozoology, and, to a lesser extent, ethnomycology. The development of these sub-disciplines promotes further ethnobiological scholarship in Ecuador. Beyond these subdisciplines, ethnobiology is interwoven with contemporary anthropological accounts that emphasize the relationships between nature and culture and shine a light on the epistemic plurality of ethnobiology. If ethnobiology in Ecuador is distinguished by an epistemic plurality-understood through these different styles of reasoning-then it can be characterized without being confined to sub-disciplines with the ethno- prefix.
\end{abstract}

Received November 24, 2017

OPENӘAACCESS

Accepted April 24, 2018

DOI 10.14237/ebl.9.2.2018.1174

Keywords Ecuador, Ethnobotany, Anthropology, Epistemic plurality, Styles of reasoning

Copyright (c) 2018 by the author(s) licensee Society of Ethnobiology. This is an open-access article distributed under the terms of the Creative Commons Attribution-NonCommercial 4.0 International Public License (https://creativecommons.org/licenses/by-nc/4.0), which permits non-commercial use, distribution, and reproduction in any medium, provided the original author and source are credited.

\section{Introduction}

Ethnobiology comprises an extensive and complex field of research focusing on the interactions between humans and their environments. Anderson et al. (2011) consider ethnobiology to be focused mainly on the knowledge of local and indigenous groups, whereas Posey (1986) perceives ethnobiology as the knowledge and conceptions developed by any society regarding nature and its role in human beliefs and adaptations to particular environments, otherwise referred to as traditional ecological knowledge (TEK). In that sense, TEK has a local explanatory scope found in the experiences of indigenous peoples. Likewise, the diálogo de saberes (Argueta 2011) seeks the recognition of the traditional ecological knowledge of local communities: their languages, their culture, and their differentiated identities, and with it the same epistemic value as science, appealing to the unyielding nature of this knowledge in the face of Western science (Agrawal 1995; Gudynas 2011; Hunn 2007). Diálogo de saberes or "dialogue of knowledge" is a dialogic process in which two or more ways of knowing that are epistemically different are encountered and sometimes confronted to solve a specific problem.

As a Latin American country, Ecuador represents a special case for the development of ethnobiology not only because of its great biodiversity and natural regions, but also for the different actors inhabiting these regions. Social actors from academia and other areas, such as government institutions and local organizations, have contributed significantly to positioning TEK in Ecuadorian scholarship and politics (e.g., including an indigenous worldview described in Ecuador's constitution). Both the Andes and the Amazon are regions of species domestication where human cultures have developed and co-evolved alongside the environment, implementing unique systems of diet, health, and worldview that have facilitated the conservation of species in these areas (Diamond 2002; Gorenflo et al. 2011). For this reason, Ecuador is recognized in its constitution as being an intercultural, plurinational, and biodiverse country. It is home to 13 indigenous nationalities, each with their own language, history, and culture, constituting self-reliant frameworks of relationships with nature (Chisaguano 2006). 
As a consequence, various disciplines including evolutionary ecology and socio-environmental studies have made important inroads with topics relevant to ethnobiology. In particular, shared concerns such as climate change, food security, and traditional knowledge have linked different fields of research in various Ecuadorian institutions. However, ethnobiology crosses other axes of research by focusing on nature conservation, ethnomedicine, bioethics, ethnoagroforestry, and diálogo de saberes; it takes as a starting point the local indigenous and Afro-descendent peoples and their own knowledge (Argueta 2011).

An analysis of ethnobiology in Latin America has shed light on the current status of ethnobiological research in the region (Albuquerque et al. 2013). Countries like Brazil and Mexico appear to be leaders in the field, while in Ecuador it seems that there is no research in this area at all. Ecuador places last in Latin America regarding scientific production specifically related to ethnobiology. Albuquerque et al. (2013) show that from 1963 to 2012, only one Ecuadorian scientific article has been published in the entire field, as opposed to 289 in Brazil, 153 in Mexico, 61 in Peru, and 11 in Colombia.

This article offers an updated overview on the current status of ethnobiological publications in Ecuador, taking into account the keywords selected by Albuquerque et al. (2013) in Scopus, an online index and database of peer-reviewed research. We include a brief search of databases from the Ecuadorian Consortium of University Libraries and the Open Access Repository Network of Ecuador. Additionally, while we use the keywords "ethnobiology" and "ethnobotany," we also use keywords without the ethno prefix, such as "useful plants", "medicinal plants", and "useful animals" in the same databases.

However, to arrive at a more comprehensive analysis of Ecuadorian ethnobiology, we argue that bibliometric research in terms of keywords is insufficient, and that meta-analysis is also required. Therefore, we also explore previous analyses of Ecuadorian ethnobiology, tracking other approaches on nature-culture relationships that reflect epistemic plurality or interdisciplinarity within ethnobiology. Finally, we discuss this epistemic plurality in terms of "styles of reasoning" in light of the so-called fifth phase of ethnobiology (Wolverton 2013).
The notion of styles of reasoning was initially proposed to explain scientific practices beyond oldfashioned views on method and was conceived as a tool to understand the historicity of science (Hacking 2009; Pickstone 2001). We believe that it also serves as a heuristic to illustrate the work of groups outside the academy, as well as the epistemic plurality underlying ethnoscience (which we understand as knowledge of, and not about, indigenous peoples). Thus, academics from local and indigenous communities, although they may not be ethnobiologists per se, have positioned their knowledge in different academic contexts and have been actors in collective processes for the recognition of their own knowledge. They recognize their TEK in terms of diálogo de saberes to maintain or promote sustainable processes, either through selfmanagement, through decentralized autonomous governments, or by the support of non-governmental organizations.

\section{Revisiting a Bibliometric Approach}

There are relatively few ethnobiological publications of Ecuadorian origin in international and indexed journals (at least, those explicitly including the prefix ethno-). The bulk of Ecuadorian research concerning nature-culture relationships appears in local publications, as is the case with the studies of medicinal flora by Misael Acosta Solis (1910-1994), and more recent research concerning the rights of nature by Acosta and Martinez (2011). Moreover, even though specialized literature on ethnobiology does exist in Ecuador (e.g., Rios 2009; De la Torre et al. 2008; Rios and Pedersen 1991), Albuquerque et al. (2013) do not recognize it as such. Instead, they recommend revisiting the state of ethnobiological studies, using a wider methodological approach to establish an overview of academic production disseminated in various educational and research institutions across the country.

Our bibliometric methodology, carried out in Scopus with the keywords "ethnobiology" and "Ecuador", showed five articles published in the period 2006-2016, which differs from results obtained by Albuquerque et al. (2013). When combining the words "ethnobotany" and "Ecuador", we found significantly more results: 50 publications in Scopus, primarily articles published in English, ignoring all contributions written in Spanish. When we used different keywords for the search, such as "medicinal 


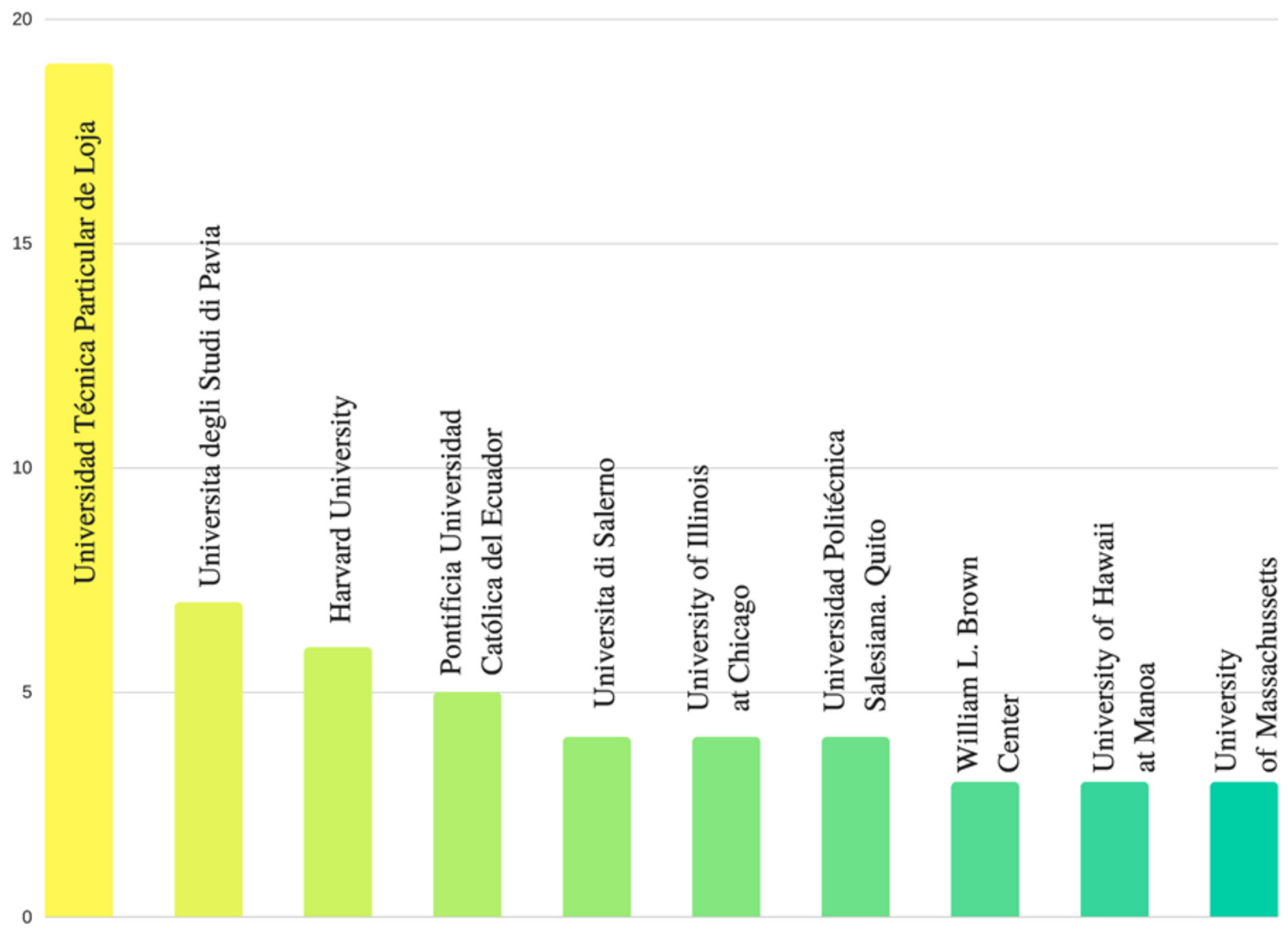

Figure 1 Institutions that are publishing about medicinal plants in Ecuador in the Scopus database.

plants" and "Ecuador", Scopus showed 96 published articles.

It is important to note that most of the articles in Scopus are publications from Ecuadorian institutions: Universidad Técnica Particular de Loja, Pontificia Universidad Católica del Ecuador, and Universidad Politécnica Salesiana. In the Open Access Repository Network of Ecuador, the list also includes the Universidad de Cuenca and Escuela Politécnica del Litoral. Over the past decade, the quantity of available publications has increased (Figures 1 and 2). Our analysis of the Ecuadorian Consortium of University Libraries database found that it includes articles, books, conference papers, and other documents related to ethnobiology in Ecuador (Figure 3), most of which are published in Spanish for national institutions.
While these bibliometric analyses allow a quick glance at scholarly production on the subject, they do not reveal an accurate picture of the status of ethnobiology in Ecuador in part because many publications in Spanish are registered in libraries and national repositories. Furthermore, these publications are not limited to keywords with the ethno- prefix, but rather address specific areas of knowledge of particular groups of people and different nationalities. We have noticed that when we focus solely on keywords with the ethno- prefix, we introduce a bias that neglects other ways of identifying ethnobiological research. Even when taking into account other keywords, we still leave aside epistemological issues that would illustrate a more comprehensive state of the discipline. 


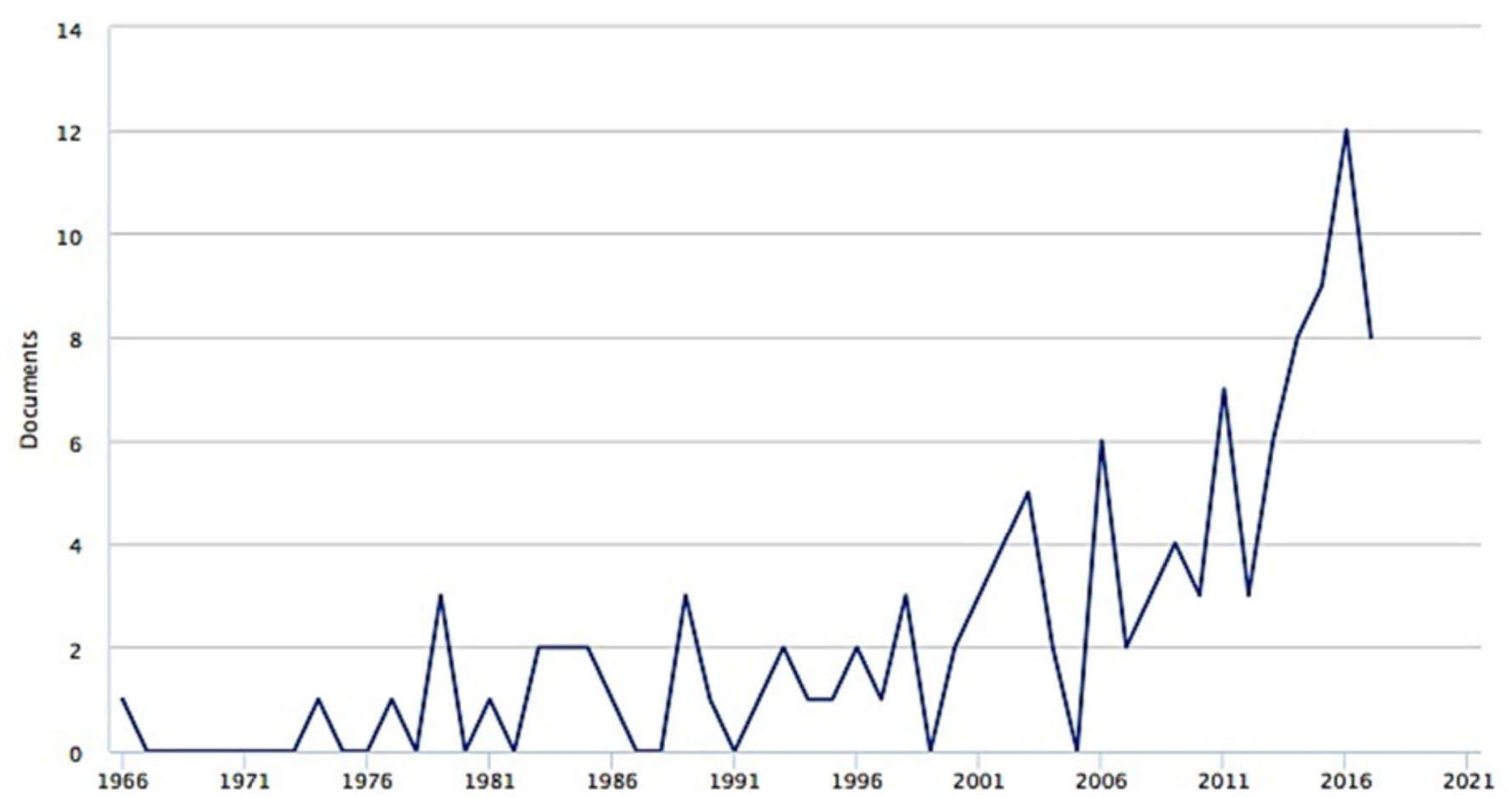

Figure 2 Number of articles published about medicinal plants in Ecuador found in the Scopus database.

\section{Beyond the Bibliometric Vision of Ethnobiology}

In her text "Las Plantas y el Hombre" ("Plants and Man"), Ana Argüello (1991) presents an analysis of ethnobiology in Ecuador. She explains that the science is gaining importance in state and private institutions, but is subject to economic limitations and lacks institutional support. Argüello presents a qualitative perspective emphasizing the separation of two research areas: on one hand, biological and botanical studies with a strong ecological perspective; on the other hand, anthropological studies that underpin a strong cultural stance. This separation is striking, particularly since anthropological efforts are recognized as being essential to ethnobiological research, especially in terms of ethnobotany.

Two recent works attempt to synthesize a historiography of Ecuadorian ethnobotany, revealing a vast number of ethnobotanical publications. These are useful for understanding the epistemological diversity that has characterized ethnobiology from its origins. The first one is a historiography of ethnobotany in Ecuador by Montserrat Ríos (2007) in collaboration with the Pontificia Universidad Católica del Ecuador and the University of Aarhus, Denmark. Ríos focuses analytically on two aspects of this subject: the category of "useful" plants, and the need to promote ethnobotany in Ecuador, encouraging the creation of repositories to contribute to environmental impact studies.

De la Torre et al (2008) wrote the second historiographical account of ethnobotany in Ecuador. It refers to the earliest settlements of the Ecuadorian region, with emphasis on archaeological data for the domestication of native species in the Sierra, the Coast, and especially in the Amazon. De la Torre et al. (2008) focus in part on the various scientific expeditions of the eighteenth century, ranging from the French Geodesic Mission, led by Charles Marie de La Condamine (started in 1739), the Spanish Botanical Expedition to the Real Audiencia de Quito, which resulted in the Flora Huayaquilensis by Juan Tafalla and Juan Agustín Manzanilla (1799-1808), to Alexander von Humboldt's expedition alongside Aimé Bonpland and Carlos Montúfar in 1799. Finally, De la Torre et al. (2008) highlight the role of several Ecuadorian ethnobotanists such as José Mejía Lequerica (17751813), Misael Acosta-Solís (1910-1994), Eduardo Estrella (1941-1996), Plutarco Naranjo (1921-2012), and Carlos Cerón (1957-).

From a critical approach to science historiography, the importance of keeping a record of national scientific production entails, on one hand, joining the criticism of the diffusionist model of Western science elaborated by George Basalla (1967), 
150

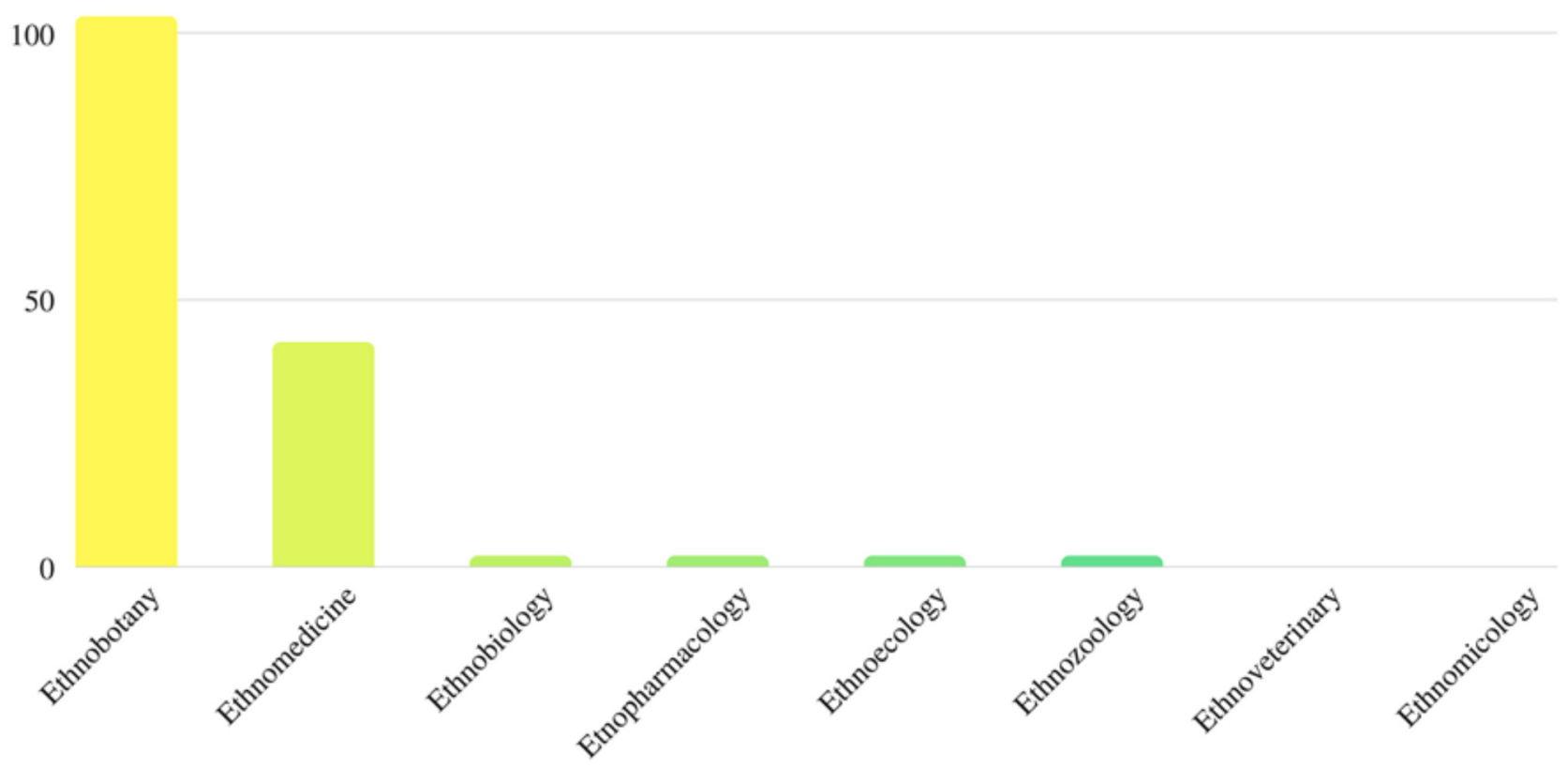

Figure 3 Publications about the ethnobiology of Ecuador found at the Consortium of University Libraries of Ecuador.

and, on the other hand, recounting what Marcos Cueto (1989) called "excellence in the periphery". This approach to Ecuadorian ethnobiology demonstrates the gestation and scientific development of a national character through the notion of research styles.

Continuing with the sub-disciplines of Ecuadorian ethnobiology, ethnomycology has works related to fungi and their relationship with humans, including studies of phytopathology, bioremediation, and biotechnology, as well as works on mushroom cultivation that could be framed as a branch of the bioeconomy. An important contribution to this field is an introduction to Ecuadorian ethnomycology by Gamboa (2009), where the author documents fungi species in 13 different ethnic communities, defining cultural uses and several worldviews around fungi.

Finally, studies in the sub-discipline of Ecuadorian ethnozoology are even more dispersed, with most of them focused on hunting or dietary taboos around meat consumption. Iván Jácome-
Negrete conducted important ethnozoological studies with emphases on the cultural uses of ichthyofauna and aquatic mammals (Jácome-Negrete 2012; JácomeNegrete et al. 2013). Jácome-Negrete argues that the beginning of Ecuadorian ethnozoology and fisheries can be traced back to 1900 and the ethnographies of different cultural groups (Jácome-Negrete 2012; Jácome-Negrete et al. 2013). This is true for most ethnobiological studies, since the first reports concerning nature-culture relationships come from the anthropological point of view.

\section{Styles of Reasoning in Ecuadorian Ethnobiology}

According to Argüello (1991), it is important to emphasize the role of anthropology in the emergence of Ecuadorian ethnobiology, from traditional approaches to indigenous groups (Barrett 1994; Bianchi 1988; Juncosa 1988; Karsten 1935; Vickers 1989), to contemporary accounts, such as the work developed by Philippe Descola (1988), Laura Rival (1996), and Eduardo Kohn (2013), among others. Likewise, juridical studies have approached the nature- 
culture relationship with a legal/environmental/ cultural focus, where the TEK of Ecuadorian peoples and nationalities have been integrated into public policies, including the national plan of Sumak Kawsay, or "Good Living", the rights of nature, and collective rights, all of which are revolutionary in terms of public policy in the Americas (De la Cadena 2010).

The origins of Ecuadorian ethnobotany are a good reminder of how ethnobiology did not begin when this science was defined (1895); instead, it originated with the accounts of explorers during the seventeenth and eighteenth centuries. Likewise, ethnomycology demonstrates the extent to which the ethnosciences involve modern, cutting-edge research areas such as engineering and genetics, without incurring a reductionist outlook.

Previous research has tried to cope with epistemic plurality in ethnobiology. For example, Eugene Hunn's four phases of ethnobiology (2007) establishes how paradigms in ethnobiology arise, but does not specify how different values coexist in the emergence of a new research field.

Hunn's first phase, defined at the end of ninetheenth century, is characterized by the first definition of ethnobiology and a utilitarian approach. The second phase, defined during the 1960s, was strongly influenced by cognitive/linguistic anthropology. The third phase integrates the ecological approach to human-nature interactions. Finally, the fourth phase, according to Hunn, emphasizes the role of indigenous people over their own rights and their own territories (Hunn 2007).

A bibliometric approach maintains a strong commitment to a conception of ethnobiology in terms of phases, neglecting both its heuristic use and the fact that one of the most relevant topics in this area presently concerns metatheory directed at biocultural phenomena (Ellen 2006).

Thus, it would be misleading to attribute Ecuadorian ethnomycology and ethnozoology to Hunn's first phase solely because they still elaborate lists of useful species while recognizing the role of people. In fact, they correspond to Hunn's fourth phase, or the so-called diálogo de saberes. We think that a meta-analysis of the current status of Ecuadorian ethnobiology implies more than the classificatory task of ethnobiological production according to Hunn's phases, as has recently been done in South Asia (Hidayati et al. 2015).
A better alternative to explain the epistemic plurality in Ecuadorian ethnobiology would utilize the metaphor of a "patchwork" employed in contemporary philosophy of science. This notion relates to different domains of scientific enterprise, using different styles of reasoning, and creating an inferential network that concerns selection, interpretation, and support of specific results (Bueno 2012; Cartwright 1999).

The notion of styles of reasoning is identified through the history of science in several works (Elwick 2007; Flech 1987); its most recent formulation concerns Ian Hacking's (2009) approach, where he argues that styles of reasoning, which aim to capture inferential patterns for relevant conditions of truth, converge in interdisciplinary projects. Such an account fits very well with the complexity and multilevel analysis of ethnobiological research. One advantage of this consideration of epistemic plurality is its convergence with the so-called fifth phase of ethnobiology, proposed by Wolverton (2013), which emphasizes that contemporary ethnobiology concerns studies of the impact of global climate change and the effects of these changes on humans and their cultures. Styles of reasoning enable researchers to link these concerns with normativity at several epistemological levels, resulting in a promising tool to map the current state of Ecuadorian ethnobiology and put forward a research agenda. A wider notion of normativity than what is usually attributed to the scientific method reflects a variety of ways of knowing which are also related to TEK, such as historical and experimental styles. Finally, styles of reasoning help to conceive of TEK as more than a classification issue.

In this context, the Ecuadorian Society of Ethnobiology and the Latin-American Society of Ethnobiology have contributed to the development of Ecuadorian ethnobiology by organizing the first and second Ecuadorian Congress of Ethnobiology (2014 and 2017 respectively), and the fifth Latin American Congress of Ethnobiology (2017). These forums have created spaces for reflection on this science, knitting together groups of researchers, and promoting the inclusion of ethnobiologist perspectives in the scholarly agenda.

Ecuadorian ethnobiology is a growing field that requires the cooperation of researchers and local communities in two ways. First, it requires the participation of local and indigenous peoples as coauthors of articles, or at least having important roles 
in the research process, and recognizing their knowledge in ethical ways. Second, ethnobiological discussions must be positioned in both academic and political spaces, including in the context of the rights of nature in order to promote the conservation of biocultural diversity.

In that sense, we encourage Ecuadorian researchers to propose new styles of reasoning that will help to position Ecuadorian ethnobiology as a tool to address the challenges that biocultural diversity currently faces, and to generate potential solutions to local and national socio-environmental crises, such as climate change and water scarcity.

\section{Declarations}

Permissions: Not applicable

Sources of Funding: Not applicable

Conflicts of Interest. None declared

\section{References Cited}

Acosta, A. and E. Martínez, 2011. La Naturaleza con Derechos: De la Filosofía a la Politica. Abya-Yala, Quito, Ecuador.

Agrawal, A. 1995. Dismantling the Divide Between Indigenous and Scientific Knowledge. Development and Change 26:413-39. DOI:10.1111/j.14677660.1995.tb00560.x.

Albuquerque, U., J. Soares, J. Loureiro, R. Silva, C. Silva, and R. Nóbrega. 2013. The Current Status of Ethnobiological Research in Latin America: Gaps and Perspectives. Journal of Ethnobiology and Ethnomedicine 9:2-9. DOI:10.1186/1746-4269-9-72.

Anderson, E. N, D. Pearsall, E. Hunn, and N. Turner, eds. 2011. Ethnobiology. Wiley, Blackwell, NJ.

Argueta, A. 2011. Introducción. In Saberes Colectivos y Diálogo de Saberes en México, edited by A. Argueta, E. Corona, and P. Hersch, pp. 11-50. National Autonomous University of México,

Argüello, A. 1991. La Etnobiología en el Ecuador. In Las Plantas y el Hombre. Memorias del Primer Simposio Ecuatoriano de Etnobotánica y Botánica Económica, edited by M. Rios and Pedersen, pp. 383-393. H. AbyaYala, Quito, Ecuador.

Barrett, S. A. 1994. Los Indios Cayapas del Ecuador. Collección Biblioteca Abya-Yala, Quito, Ecuador.

Basalla, G. 1967. The Spread of Western Science. A Three-Stage Model Describes the Introduction of Modern Science into Any Non-European Nation.
Science 156:611-622. DOI:10.1126/

science.156.3775.611.

Bianchi, C. 1988. El Shuary el Ambiente. Mundo Shuar, Quito, Ecuador.

Bueno O. 2012. Styles of Reasoning: A Pluralist View. Studies in History and Philosophy of Science 43:657-665. DOI:10.1016/j.shpsa.2012.07.008

Cartwright N. 1999. The Dappled World. A Study of the Boundaries of Science. Cambridge University Press. Cambridge.

Chisaguano, S. 2006. La Población Indígena del Ecuador. Instituto Nacional de Estadística y Censos (INEC) Quito, Ecuador.

Cueto, M. 1989. Excelencia Cientifica en la Periferia: Actividades Cientificas e Investigación Biomédica en el Perú 1890-1950. Grade, Lima, Perú.

De la Cadena, M. 2010. Indigenous Cosmopolitics in the Andes: Conceptual Reflections Beyond "Politics". Cultural Anthropology 25:334-370.

De la Torre, L., H. Navarrete, M. Muriel, M. Macía, and H. Balslev, eds. 2008. Enciclopedia de las Plantas Útiles del Ecuador. Herbario QCA de la PUCE y Herbario AAU de la Universidad de Aarhus, Quito, Ecuador.

Descola, P. 1988. La Selva Culta. Abya-Yala, Quito, Ecuador.

Diamond, J. 2002. Evolution, Consequences, and Future of Plant and Animal Domestication. Nature 418:700-707. DOI:10.1038/nature01019.

Ellen, R. 2006. Introduction. Journal of the Royal Anthropological Institute 12:1-22. DOI:10.1111/j.14679655.2006.00270.x.

Elwick, J. 2007. Styles of Reasoning in the British Life Sciences: Shared Assumptions, 1820-1858. Pickering and Chatto, London.

Fleck, L. 1987. Génesis y Desarrollo de un Hecho Cientifico: Introducción a la Teoría del Estilo de Pensamiento y del Colectivo de Pensamiento. Alianza Editorial, Madrid, Spain.

Gamboa-Trujillo, J.P. 2009. Introdução à

Etnomicologia no Equador. Unpublished Doctoral Dissertation. Programa de Pós-Graduação em Biologia de Fungos. Universidade Federal de Pernambuco (UFPE), Brazil.

Gorenflo, L., S. Romaine, R. Mittermeier, and K. Walker-Painemilla. 2012. Co-Occurrence of Linguistic and Biological Diversity in Biodiversity 
Hotspots and High Biodiversity Wilderness Areas. PNAS 109:8032-8037. DOI:10.1073/ pnas.1117511109.

Gudynas, E. 2011. Los Derechos de la Naturaleza en Serio. In La Naturaleza con Derechos. de la Filosofía a la Política, edited by A. Acosta and E. Martínez, pp. 239-286. Abya-Yala, Quito, Ecuador.

Hacking, I. 2009. Scientific Reason. Institute for Advanced Studies in Humanities and Social Sciences, National Taiwan University, Taipei, Taiwan.

Hidayati, S., F. Franco, and W. Bussmann. 2015. Ready for Phase 5-Current Status of Ethnobiology in Southeast Asia. Journal of Ethnobiology and Ethnomedicine 11:2-8. DOI:10.1186/s13002-0150005-7.

Hunn, E. 2007. Ethnobiology in Four Phases. Journal of Ethnobiology 27:1-10. DOI:10.2993/0278-0771 (2007)27[1:EIFP]2.0.CO;2.

Jácome-Negrete, I. 2012. Etnoictiología Kichwa de los Bagres del Género Pseudoplatystoma (Siluriformes: Pimelodidae) en la Amazonía Central del Ecuador. Revista Amazónica Ciencia y Tecnología 1:36-50.

Jácome-Negrete, I., V. Tanchima, P. Santi, C. Vargas. 2013. Etnozoología Quichua para la Conservación de los Mamíferos Ungulados en la Amazonía Central del Ecuador Provincia Pastaza. Revista Amazónica Ciencia y Tecnología 2(3):1-14.

Juncosa, J. 1988. Tsachila: Los Clásicos de la Etnografía Sobre los Colorados (1905-1950). Abya-Yala, Quito, Ecuador.

Karsten, K. 1935. The Head Hunters of Western Amazonas. Societas Scientiarum Fenica. Commentatores Humanarum Litterarum, Helsinki, Finland.
Kohn, E. 2013. How Forests Think: Toward an Anthropology Beyond the Human. University of California Press, CA.

Pickstone, J. 2001. Ways of Knowing. A New History of Science, Technology, and Medicine. University of Chicago Press, Chicago, IL.

Posey, D. 1986. Etnobiologia: Teoria e Prática. In Summa Etnologica Brasileira, edited by P. Ribeiro, pp. 15-25. Vozes/FINEP, Petropolis, Brasil.

Ríos, M. 2007. La Etnobotánica en el Ecuador. Síntesis, Retos, y Perspectivas. In Plantas Útiles del Ecuador. Aplicaciones, Retos, y Perspectivas, edited by M. Rios, M. Koziol, H. Pedersen, and G. Granda, pp. 17-41. Herbario QCA PUCE/Herbario AAU/The Exotic Blends Company/Corporación Sociedad para la Investigación y Monitoreo de la Biodiversidad Ecuatoriana (SIMBIOE), Quito, Ecuador.

Ríos and Pedersen 1991. Las Plantas y el Hombre. Memorias del Primer Simposio Ecuatoriano de Etnobotánica y Botánica Económica. Abya-Yala, Quito, Ecuador.

Rival, L. 1996. Blowpipes and Spears: The Social Significance of Huaorani Technological Choices. In Nature and Society: Anthropological Perspectives, edited by P. Descola and G. Palsson, pp. 145-164. Siglo XXI. Ciudad de México, México.

Vickers, W.T. 1989. Los Sionas y Secoyas. Su Adaptación al Ambiente Amazónico. Colección 500 Años. AbyaYala, Cayambe, Ecuador.

Wolverton, S. 2013. Ethnobiology 5: Interdisciplinarity in an Era of Rapid Environmental Change. Ethnobiology Letters 4:21-25. DOI:10.14237/ ebl.4.2013.11. 